Materiales de Construcción

Vol. 67, Issue 325, January-March 2017, e111

ISSN-L: 0465-2746

http://dx.doi.org/10.3989/mc.2017.09315

\title{
The use of a volcanic material as filler in self-compacting concrete production for lower strength applications
}

\author{
D. Burgos ${ }^{\mathrm{a}} \bowtie$, A. Guzmán ${ }^{\mathrm{a}}$, K.M.A. Hossain ${ }^{\mathrm{b}}$, S. Delvasto ${ }^{\mathrm{a}}$ \\ a. Grupo de Materiales Compuestos (GMC), Escuela de Ingeniería de Materiales, Universidad del Valle (Cali, Colombia) \\ b. Department of Civil Engineering, Ryerson University (Toronto, Canada) \\ $\triangle$ diana.burgos@correounivalle.edu.co
}

Received 3 November 2015 Accepted 13 June 2016

Available on line 20 January 2017

\begin{abstract}
This study evaluates the use of large amounts of fine powders (fillers) derived from a Colombian volcanic material into the production of self-compacting concrete (SCC) for lower strength applications. The effects on SCC properties were studied with the incorporation of up to $50 \%$ of volcanic material of Tolima (MVT) as a partial substitute of the total weight of Portland cement. The workability was determined through slump flow, V-funnel, and L-box test. The compressive strength results were analyzed statistically by MINITAB. These demonstrated that $30 \%$ (by total weight of cementitious material) was the maximum allowable percentage of MVT to be used in the production of SCCs. Based on this, mechanical and permeability properties of SCC MVT 30\% were evaluated at 28, 90 y 360 curing days. SCC MVT 30\% exhibited compressive strength of 21 and $27 \mathrm{MPa}$ after 28 and 360 days of curing, respectively.
\end{abstract}

KEYWORDS: Self-compacting concrete; Filler; Workability; Compressive strength; Permeability

Citation/Citar como: Burgos, D.; Guzmán, A.; Hossain, K.M.A.; Delvasto, S. (2017) The use of a volcanic material as filler in self-compacting concrete production for lower strength applications. Mater. Construcc. 67 [325], e111. http://dx.doi.org/10.3989/mc.2017.09315

\begin{abstract}
RESUMEN: Uso de un material volcánico como filler en la producción de hormigones autocompactantes de baja resistencia. Este trabajo presenta los resultados de utilización de cantidades elevadas de material volcánico colombiano como filler en la producción de hormigón autocompactante (CAC) de baja resistencia. Se estudió el efecto sobre las propiedades de los CACs de la incorporación del material volcánico del Tolima (MVT) hasta en $50 \%$ como remplazo parcial del peso total del cementante. La trabajabilidad fue determinada por medio del flujo de asentamiento, embudo V y Caja L. El análisis de resistencia a la compresión por medio de MINITAB demostró que el máximo porcentaje de incorporación de MVT en los CACs es del 30\% respecto al peso total de cementante. Con base en esta optimización se evaluaron sus propiedades mecánicas y de permeabilidad a 28, 90 y 360 días de curado. Los resultados demostraron que este CAC MVT 30\% presentó resistencias a compresión de 21 y 27 MPa después de 28 y 360 días de curado, respectivamente.
\end{abstract}

PALABRAS CLAVE: Hormigón autocompactante; Filler; Trabajabilidad; Resistencia a la compresión; Permeabilidad

ORCID ID: D. Burgos (http://orcid.org/0000-0003-1944-8596); A. Guzman (http://orcid.org/0000-0001-9226-4852); K.M.A. Hossain (http://orcid.org/0000-0002-7686-6957); S. Delvasto (http://orcid.org/0000-0001-9443-8238)

Copyright: (C) 2017 CSIC. This is an open-access article distributed under the terms of the Creative Commons Attribution License (CC BY) Spain 3.0.

\section{INTRODUCTION}

Self-compacting concrete (SCC) has been gaining popularity in the construction industry in recent years because of its numerous advantages over the conventional concrete. Most important advantages of the SCC include a shorter construction time, improved conditions for workers because mechanical vibration is not necessary, and its easier application in complex architectural designs and densely 
reinforced structures (1). Numerous researches have studied the use of alternative materials for the production of SCCs in order to increase their acceptance and reduce the cement consumption while maintaining a high fine content to preserve selfcompactability characteristic. Rodríguez et al. (2) evaluated the possibility of obtaining lower-strength SCC using cement kiln dust (CKD) as a partial replacement of the cement, and found that the use of high percentages of CKD and different combinations of water/fines ratio allowed the optimization of the amount of cement required to obtain SCC of medium strength with lower production costs. Several researchers have developed SCCs with high percentages of marble powders (3), limestone powders (4), and wastes from palm oil and fly ash (5).

Volcanic materials are formed during volcanic eruptions, and their vitreous state depends on the magma composition and the solidification process (6). The reactivity of volcanic materials is determined by the chemical composition, physical structure of the particles and their potential to react and form cementing compounds (7). The volcanic materials have been widely utilized in the production of blended cements for their properties and worldwide availability. Regarding of SCC, researchers such as Hossain and Lachemi (8) investigated the use of volcanic ash as a partial replacement of cement in the production of economical and environmentally friendly SCCs with good mechanical and durability properties. Güneyisi et al. (9) evaluated the influence of incorporating volcanic pumice stone powder (VP) in the fresh properties of SCC. The results demonstrated that the fluidity of SCCs increased with VP content without segregation. Celik et al. (10) utilized natural volcanic pozzolan and limestone powder into the production of SCC with high compressive strength and high resistance to chloride ion penetration. Usually SCC has been widely used in the ready-mixed concrete industry for structural applications. However, this concept has led to a moderate development of the use of SCC in some applications or products where lower strength is required. Hence this paper evaluates the use of large amounts of fine powders (fillers) derived from a Colombian volcanic material to be incorporated into the production of SCC for lower strength applications.

\section{EXPERIMENTAL METHODS}

\subsection{Materials}

Type I Portland cement with a particle size of $22 \mu \mathrm{m}$ was used for this study, and it met the specifications of the Colombian standard NTC 321. A river sand was used as fine aggregate and limestone crusher with a maximum nominal size of $12.7 \mathrm{~mm}$ was used as coarse aggregate. The bulk densities of the aggregates were $2,581 \mathrm{~kg} / \mathrm{m}^{3}$ and $2,544 \mathrm{~kg} / \mathrm{m}^{3}$, and their water absorptions were $1.89 \%$ and $2.01 \%$, respectively. A latest generation superplasticizer (SP) was utilized, which meets the requirements of ASTM C494 (11) types A and F, with a specific gravity of $1130 \mathrm{~kg} / \mathrm{m}^{3}$ and $\mathrm{pH}$ of 5 .

The volcanic material was originated in the Nevado del Tolima volcano, located in the cordillera central in the Colombian department of Tolima. This material was subjected to grinding processes until a mean particle size of $20.2 \mu \mathrm{m}$ was obtained. Table 1 shows the physical and chemical properties of the volcanic material from the Tolima volcano (MVT) and of type I Portland cement. MVT is mainly composed of silica (close to 64\%), whereas the main component of the cement is calcium oxide. The high loss on ignition of cement is caused by the incorporation of limestone materials during its production. The MVT also contains alumina, iron oxide and calcium oxide. The total amount of sodium, magnesium and potassium oxides known as "alkalis" are higher in MVT $(8.67 \%)$ than the permissible content in cement $(2.6 \%$ maximum). The higher content of alkalis in MVT may have damaging effects leading to disintegration of concrete due to reaction with

TABle 1. Chemical and physical properties of Portland cement and volcanic material from the Tolima volcano (MVT)

\begin{tabular}{|c|c|c|}
\hline & $\begin{array}{l}\text { Type I Portland } \\
\text { cement }\end{array}$ & MVT \\
\hline \multicolumn{3}{|l|}{ Chemical composition (\%) } \\
\hline $\mathrm{SiO}_{2}$ & 20.73 & 64.36 \\
\hline $\mathrm{Fe}_{2} \mathrm{O}_{3}$ & 5.63 & 4.92 \\
\hline $\mathrm{Al}_{2} \mathrm{O}_{3}$ & 4.54 & 15.90 \\
\hline $\mathrm{CaO}$ & 52.69 & 4.71 \\
\hline $\mathrm{Na}_{2} \mathrm{O}$ & 0.15 & 5.38 \\
\hline $\mathrm{MgO}$ & 2.24 & 1.80 \\
\hline $\mathrm{TiO}_{2}$ & 0.24 & 0.54 \\
\hline $\mathrm{P}_{2} \mathrm{O}_{5}$ & 0.14 & 0.17 \\
\hline $\mathrm{K}_{2} \mathrm{O}$ & 0.41 & 1.49 \\
\hline $\mathrm{SO}_{3}$ & 3.14 & - \\
\hline $\mathrm{SrO}$ & 0.16 & - \\
\hline $\mathrm{Mn}_{2} \mathrm{O}_{3}$ & 0.06 & - \\
\hline $\mathrm{Cr}_{2} \mathrm{O}_{3}$ & 0.03 & - \\
\hline $\mathrm{ZnO}$ & 0.01 & - \\
\hline $\mathrm{Zr}$ & - & 0.01 \\
\hline $\mathrm{MnO}$ & - & 0.09 \\
\hline $\mathrm{Zn}$ & - & 0.01 \\
\hline $\mathrm{Sr}$ & - & 0.09 \\
\hline $\mathrm{Ba}$ & - & 0.08 \\
\hline LOI & 9.85 & 0.40 \\
\hline Specific Gravity $\left(\mathrm{kg} / \mathrm{m}^{3}\right)$ & 3100 & 2090 \\
\hline Mean particle size $(\mu \mathrm{m})$ & 22.00 & 20.20 \\
\hline
\end{tabular}


certain forms of silica in aggregates (reactive aggregates) to form a product that expands in the presence of moisture and results in deleterious cracking (12). However, in this particular case the aggregates used did not contain reactive silica materials (these aggregates were not reactive).

On the other hand, the loss on ignition and specific gravity of MVT are $0.4 \%$ and $2,090 \mathrm{~kg} / \mathrm{m}^{3}$, respectively. Earlier studies on characterization $(13,14)$ showed that MVT was an inert material, because it did not present reactivity with the calcium hydroxide $\left(\mathrm{Ca}(\mathrm{OH})_{2}\right)$ produced by the cement hydration process. Despite this, it was decided to incorporate the MVT as a partial replacement of the total weight of Portland cement into SCC to evaluate the possibility of reducing the consumption of cement and thereby promoting the use of this kind of concrete in applications where lower strength is required such as the precast industry.

Figure 1 shows the petrographic micro-images of MVT which shows that this material is composed of dispersed phenocryst of tubular plagioclases $(\mathrm{Pg})$ and subhedral quartz $(\mathrm{Qz})$ of small size, floating on a hypo-crystalline amorphous vitreous matrix, where small plagioclase crystals are dispersed showing no preferred orientation. The X-ray diffraction pattern of MVT (Figure 2) supports the petrographic analysis demonstrating that MVT is predominantly crystalline, mainly composed of Albite with max peak intensity $2 \theta \approx 28.059$ and lower intensity peaks corresponding to Anorthite and Andesine, which are plagioclase minerals. Furthermore, MVT also has minerals such as Zeolite, Quartz, Cordierite and Diopside. The results obtained for mineralogical composition indicate that MVT was produced by non-explosive volcanic eruptions gradually getting cold resulting into a predominantly crystalline structure. The particle size distributions of MVT and Portland cement are presented in Figure 3. These curves shows that MVT has a particle size distribution similar to that of Portland cement. However MVT presents a higher (a)

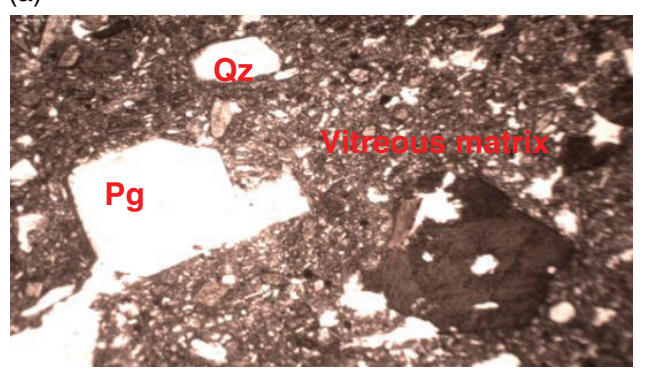

(b)

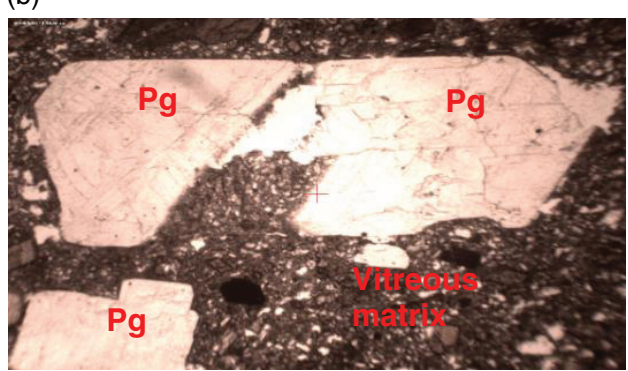

FIGURE 1. Petrographic thin sections of Tolima volcanic material.

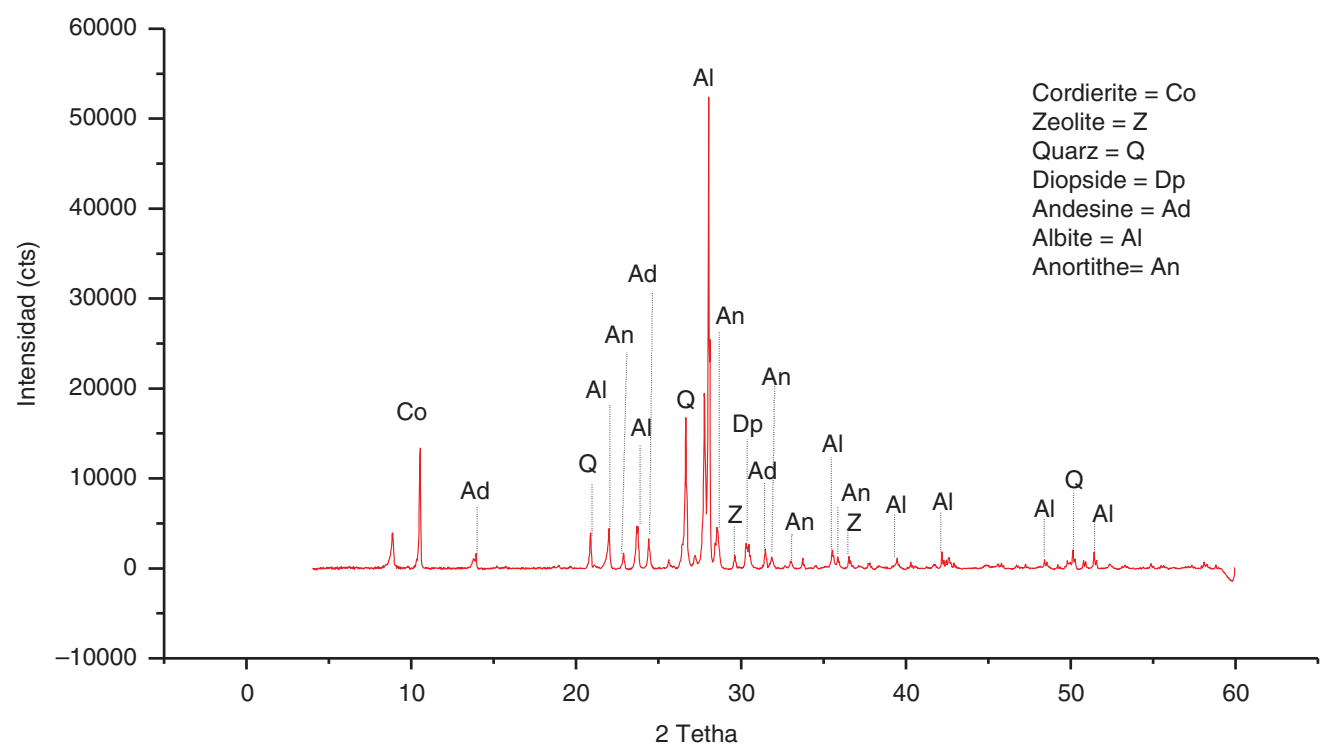

FIGURE 2. X-ray diffraction patterns of Tolima volcanic materials. 
volume of particles with a size less than $10 \mu \mathrm{m}$ compared with the Portland cement. Hence, these particles could fill voids between the larger particles and would improve the fluidity of self-compacting concrete in the fresh state and could influence the development of hardened properties. The morphology of MVT particles is presented in Figure 4. The micro-image (Figure 4a) shows various particles of irregular morphology and different sizes produced by grinding process, which confirms the granulometry results presented above. The micro-image (Figure 4b) shows that MVT particles have angular morphology due to exfoliation process, which is the characteristic of crystalline materials, because this kind of materials are fragmented through their crystallographic planes. The particle shape, particle size distribution, particle packing effects and the surface texture, could affect the water demand of the mixture and the workability of the concrete in fresh state (15).

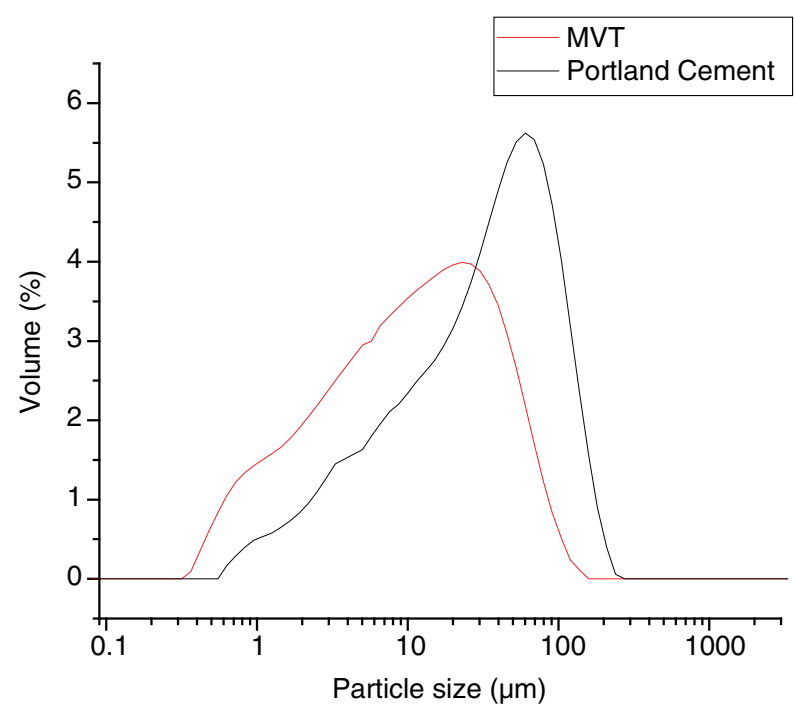

FIGURE 3. Particle size distribution of Tolima volcanic material and Portland cement.

\subsection{Mixture proportions}

An extreme vertices design of mixtures experiments was used in order to evaluate the effect of different mass percentages of MVT addition in SCC and to find the optimal proportion of incorporation that ensured adequate properties in fresh and hardened states. The response variable was the development of compressive strength over 28-day curing time. The tests were performed and randomized using the MINITAB 16 software package and the treatments are presented in Table 2.

The SCCs mixture proportions are presented in Table 3. The incorporation of MVT was from 20\% to $50 \%$ by total weight of Portland cement of the SCC of reference. All mixtures had a total content of cementitious material (Portland cement + MVT) of $480 \mathrm{~kg} / \mathrm{m}^{3}$, the water/cementitious materials ratio was kept constant at 0.47 , and the dosage of SP was adjusted and optimized to achieve the fresh state properties of an SCC. The dosage of SP ranged from $0.55 \%$ to $0.60 \%$ by weight with respect to the total cementitious material. In this particular case, it was decided to keep constant the proportion of aggregates in all mixtures evaluated, mainly because the effect of varying the proportion of aggregates was not known, and only it was desired to evaluate the effect of incorporation of MVT into the production of SCC. In this sense (for the design of SCC), it was assumed that MVT had the same density of Portland cement and thus the mix proportions was calculated by $1 \mathrm{~m}^{3}$ of concrete.

\subsection{Tests}

After preparing the SCC mixtures as per experimental design, their fresh state properties, such as the filling capacity, passing ability, and resistance to segregation, were evaluated by slump flow, $\mathrm{V}$ funnel and L box tests, respectively according to the procedures and ranges established by the European specifications for SCC presented in Table 4 (16). Each mixture of SCC was cast

(b)

(a)
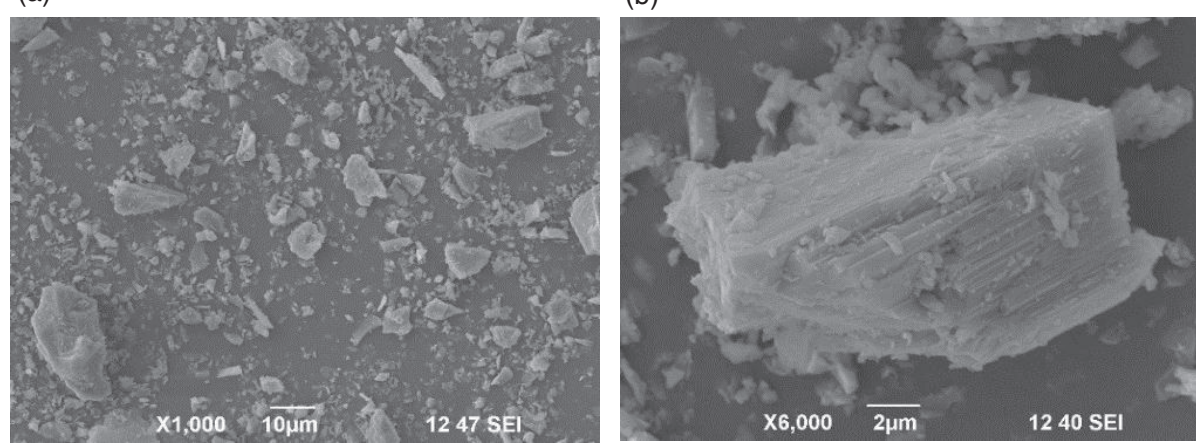

FIGURE 4. SEM micro-images of Tolima volcanic materials at magnification: a) 1000X y b) 6000X. 
The use of a volcanic material as filler in self-compacting concrete production $\bullet 5$

TABLE 2. Optimization treatments of the proportions of MVT with respect to Portland cement content

\begin{tabular}{lccccc}
\hline StdOrder & RunOrder & PtType & Blocks & MVT & $\begin{array}{c}\text { Type I Portland } \\
\text { Cement }\end{array}$ \\
\hline 5 & 1 & -1 & 1 & 0.43 & 0.57 \\
6 & 2 & 0 & 1 & 0.35 & 0.65 \\
7 & 3 & 0 & 1 & 0.35 & 0.65 \\
3 & 4 & 0 & 1 & 0.35 & 0.65 \\
4 & 5 & -1 & 1 & 0.28 & 0.72 \\
2 & 6 & 1 & 1 & 0.50 & 0.50 \\
1 & 7 & 1 & 1 & 0.20 & 0.80 \\
\hline
\end{tabular}

TABLE 3. Proportions of the self-compacting concretes

\begin{tabular}{|c|c|c|c|c|c|c|c|c|}
\hline \multirow[b]{2}{*}{ SCC mixtures } & \multirow[b]{2}{*}{$\mathbf{W} / \mathbf{C}^{*}$} & \multirow[b]{2}{*}{ Water $\left(\mathrm{kg} / \mathrm{m}^{3}\right)$} & \multirow[b]{2}{*}{ Cement $\left(\mathrm{kg} / \mathrm{m}^{3}\right)$} & \multicolumn{2}{|c|}{ Volcanic material (MVT) } & \multicolumn{3}{|c|}{ Aggregates $\left(\mathrm{kg} / \mathrm{m}^{3}\right)$} \\
\hline & & & & $\mathrm{kg} / \mathrm{m}^{3}$ & $\%$ & Sand & Gravel & $\% \mathrm{SP}+$ \\
\hline & & & -Compacting Cor & rete of Re & $0 \% M V$ & & & \\
\hline \multirow[t]{2}{*}{ REFERENCE } & 0.47 & 226 & 480 & 0 & 0 & 950 & 633 & 0.55 \\
\hline & \multicolumn{8}{|c|}{ Self-Compacting Concrete with added MVT } \\
\hline MVT $20 \%$ & 0.47 & 226 & 384 & 96 & 20 & 950 & 633 & 0.55 \\
\hline MVT $28 \%$ & 0.47 & 226 & 346 & 134 & 28 & 950 & 633 & 0.55 \\
\hline MVT $35 \%$ & 0.47 & 226 & 312 & 168 & 35 & 950 & 633 & 0.55 \\
\hline MVT $42 \%$ & 0.47 & 226 & 278 & 202 & 42 & 950 & 633 & 0.6 \\
\hline MVT 50\% & 0.47 & 226 & 240 & 240 & 50 & 950 & 633 & 0.6 \\
\hline
\end{tabular}

$C^{*}=$ Cementitious Material (Portland cement $+M V T$ ).

$\boldsymbol{S} \boldsymbol{P}^{+}=$Superplasticizer .

TABLE 4. Specifications of the European guidelines for self-compacting concrete.

\begin{tabular}{lccc}
\hline & Test methods & Unit & European guidelines values \\
\hline Filling capacity & SF1 class slump flow & $\mathrm{mm}$ & $550-650$ \\
& SF2 class slump flow & $\mathrm{mm}$ & $660-750$ \\
& SF3 class slump flow & $\mathrm{mm}$ & $760-850$ \\
& T50 VF1 & $\mathrm{s}$ & $<2$ \\
T50 VF2 & $\mathrm{s}$ & $>2$ \\
VF1 class V funnel & $\mathrm{s}$ & $\leq 8$ \\
Vassing ability & $\mathrm{s}$ class V funnel & $\left(\mathrm{h}_{2} / \mathrm{h}_{1}\right)$ & $\geq 0.80$ with 2 bars \\
& PA1 class L box & $\left(\mathrm{h}_{2} / \mathrm{h}_{1}\right)$ & $\geq 0.80$ with 3 bars \\
\hline
\end{tabular}

without hand or mechanical vibration in cylindrical samples of dimensions $76.2 \times 152.4 \mathrm{~mm}$ for compressive strength evaluation. After casting all the specimens were covered with humid burlap and left at room temperature for $24 \mathrm{~h}$. They were then demolded and transferred to the moist curing room at $100 \%$ relative humidity until testing.
After 28 days of curing, the compressive strengths of the mixtures were evaluated following ASTM C39/C39M-12 (17) and the results were analyzed using the MINITAB 16 software package in order to obtain the optimal proportion of incorporation of MVT in the SCCs. After the selection of MVT proportion, SCCs were produced using 
the chosen proportion of MVT, and their compressive strength, tensile strength (as per ASTM C496) (18) and flexural strength (as per ASTM C78) (19) were evaluated at 7, 28 and 90 curing days. In addition, density, water absorption, and voids in hardened concrete were evaluated following ASTM C642 (20) using prism-shaped samples of dimensions $76.2 \times 76.2 \times 70.0 \mathrm{~mm}$. Lastly the measurement of sorptivity of concrete was evaluated following the European standard (SIA 162/1) (21) using prism-shaped samples of dimensions $76.2 \times 76.2 \times 70.0 \mathrm{~mm}$.

\section{RESULTS AND ANALYSIS}

\subsection{Fresh state properties of the SCCs with different proportions of added MVT}

Figure 5 presents the fresh state properties of reference SCC $(0 \%$ MVT) and SCCs with different MVT percentages. The test results demonstrated that all mixtures achieved the parameters established by the European guidelines for SCC. According to MVT proportions different classes of self-compacting concretes can be obtained. For example, the incorporation of $20 \%$ and $28 \%$ of MVT increased the fluidity of the SCCs, as was evidenced by high values of slump flow and low times of $\mathrm{T}_{50}$ and $\mathrm{V}$ funnel compared with the reference SCC. Even keeping the same dosage of SP and the same water/cementitious ratio in these SCC. Generally, these classes of SCCs had good filling ability and could be used for vertical applications (walls and columns) in very congested structures. However, incorporation of $35 \%$ or more of MVT, the cohesivity of the mixture increased. For this reason, slump flow and L-box ratio (h2/h1) decreased. Also, these mixtures showed an increase in flow times $\left(\mathrm{T}_{50}\right.$ and $\left.\mathrm{T}_{\mathrm{v}}\right)$. As a result, the dosage of $\mathrm{SP}$ was increased up to $0.60 \%$ for mixes using $42 \%$ to $50 \%$ of MVT in order to guarantee that these mixtures achieved the minimal parameters established for SCCs. According to these results, SCCs with $30 \%$, $42 \%$ and $50 \%$ of MVT showed appropriate characteristics for unreinforced or slightly reinforced concrete structures, or casting by a pump injection system. The results in fresh state demonstrated that MVT could behave as a viscosity modifying agent that improve the concrete fluidity but at the same time can reduce sensitivity of the mix to segregation. However, these results should be supported later by rheological tests. Uysal and Yilmaz (22) reported that mixtures containing mineral admixtures generally showed better performance than the control mixtures in regards to workability due to better particle distribution and reduction in interparticle friction leading to increased packing density and decreased flow resistance.

\subsection{Optimization of the proportions of volcanic material from Tolima volcano}

The compressive strength tests results were analyzed mathematically with the MINITAB 16 program. A quadratic regression model (Eq. [1]) was found suitable for relating compressive strength (Y)
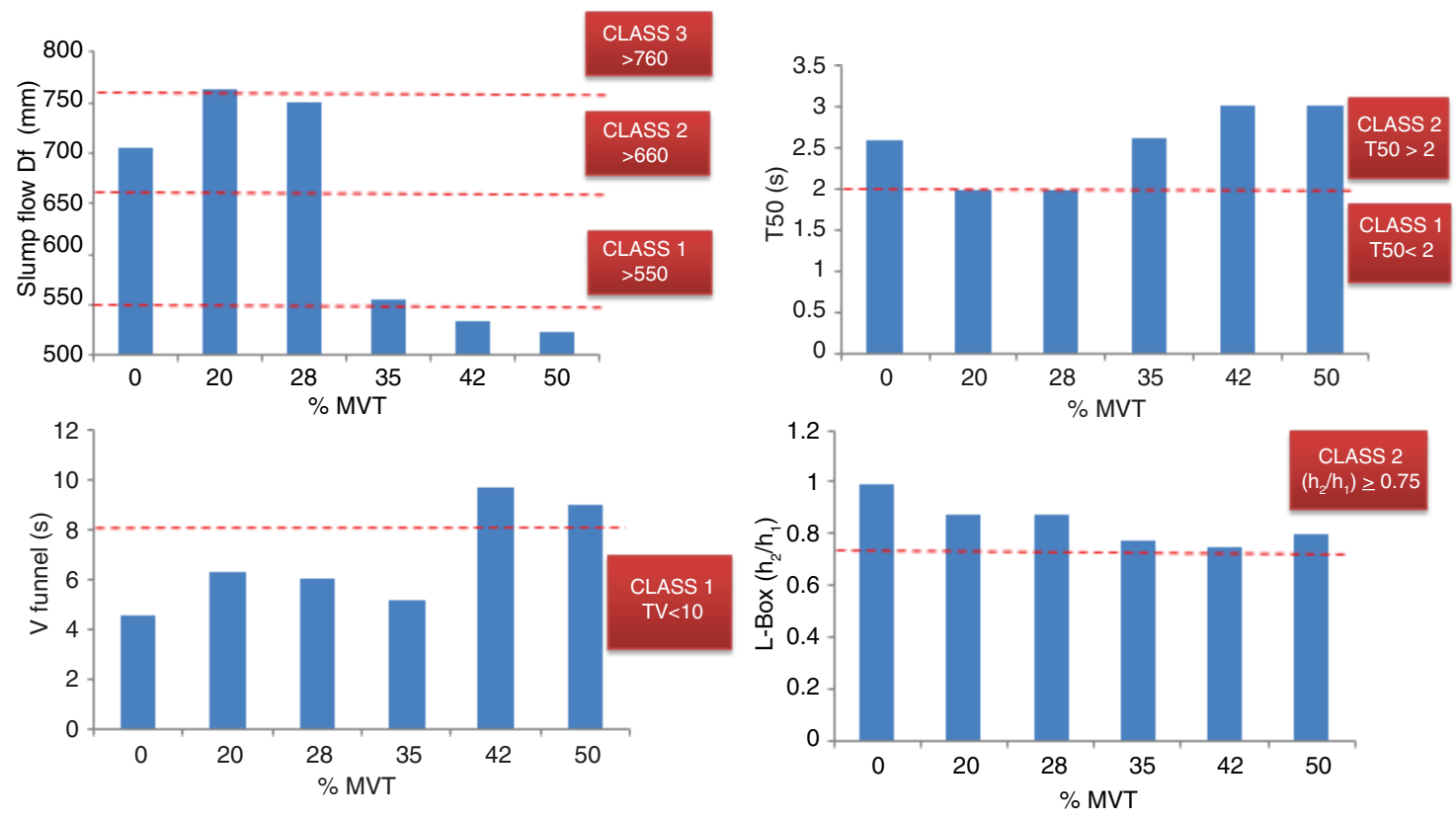

FIGURE 5. Fresh state properties of self-compacting concretes with added MVT. 


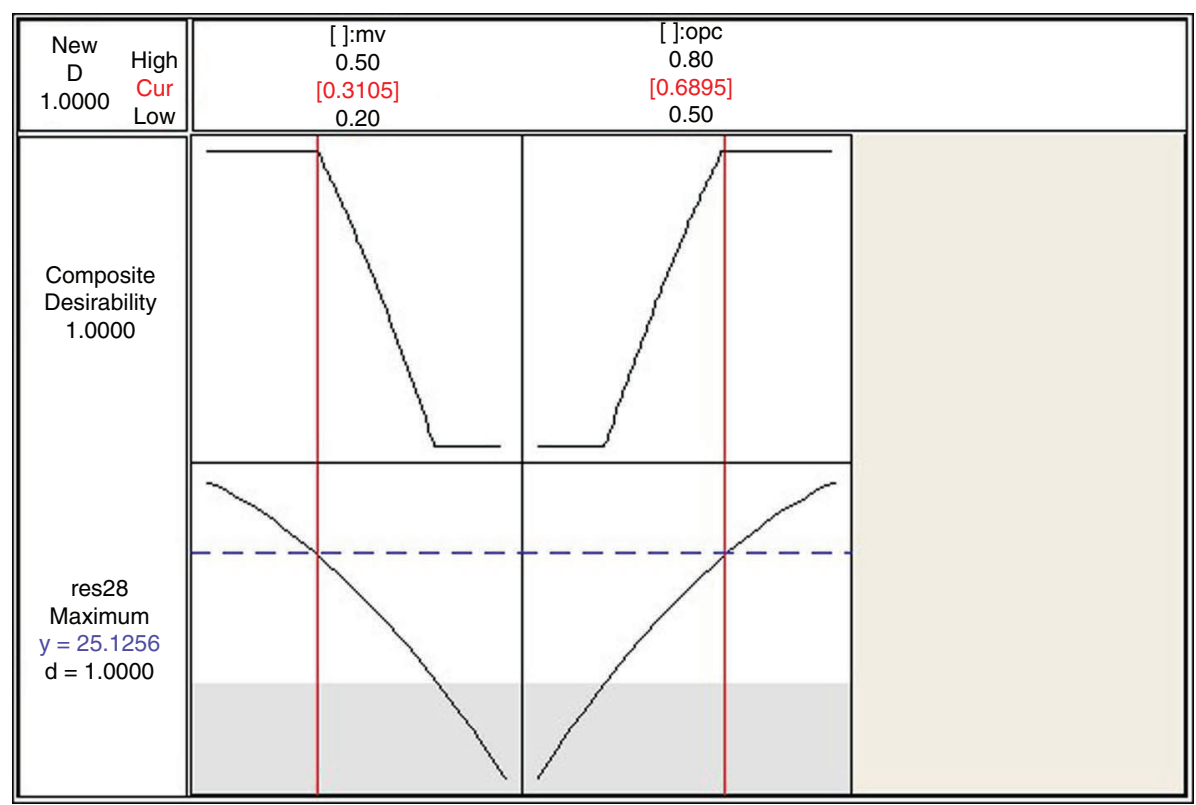

FIGURE 6. Optimization of the proportions of MVT in self-compacting concretes in terms of compressive strength after 28 curing days.

TABLE 5. Mixture proportions of self-compacting concrete with 30\% MVT (SCC MVT 30\%)

\begin{tabular}{|c|c|c|c|c|c|c|c|c|}
\hline \multirow{2}{*}{$\begin{array}{l}\text { SCC } \\
\text { mixture }\end{array}$} & \multirow[b]{2}{*}{$\mathbf{W} / \mathbf{C}^{*}$} & \multirow{2}{*}{$\begin{array}{c}\text { Water } \\
\left(\mathrm{kg} / \mathrm{m}^{3}\right)\end{array}$} & \multirow{2}{*}{$\begin{array}{l}\text { Cement } \\
\left(\mathrm{kg} / \mathrm{m}^{3}\right)\end{array}$} & \multicolumn{2}{|c|}{ Volcanic material (MVT) } & \multicolumn{2}{|c|}{ Aggregates $\left(\mathrm{kg} / \mathrm{m}^{3}\right)$} & \multirow[b]{2}{*}{$\% \mathrm{SP}+$} \\
\hline & & & & $\mathrm{kg} / \mathrm{m}^{3}$ & $\%$ & Sand & Gravel & \\
\hline MVT $30 \%$ & 0.47 & 226 & 336 & 144 & 30 & 950 & 633 & 0.55 \\
\hline
\end{tabular}

$\mathrm{C}^{*}=$ Cement mixture (Ordinary Portland cement + MVT).

with the mix design parameters $\left(\mathrm{X}_{1}\right.$ and $\left.\mathrm{X}_{2}\right)$ subjected to a significance level of $5 \%$.

$$
\boldsymbol{Y}=7.63 \boldsymbol{X}_{1}+30.79 \boldsymbol{X}_{\mathbf{2}}+12.33 \boldsymbol{X}_{\mathbf{1}} \boldsymbol{X}_{\mathbf{2}}+\varepsilon
$$

Where $\mathbf{X}_{1}, \mathbf{X}_{2}$ are MVT and Ordinary Portland Cement (OPC) proportions, respectively and $\varepsilon$ is the error.

The analysis of variance (ANOVA) obtained for compressive strength ( $\mathrm{p}$ value, coefficient of multiple determination $\mathrm{R}^{2}$ and adjusted coefficient of multiple determination, $R_{A}^{2}$ ), shows that the model is statistically significant at the required level ( $\mathrm{p}$ value $(0.047) \leq$ significance level $(0.050))$ and presented small variability $\left(\mathrm{R}^{2}=0.891\right.$ and $\left.R_{A}^{2}=0.878\right)$. The results of lack-of-fit test were used to verify the adequacy of the models. In this case, the p value (0.644) exceeded the significance level $(0.050)$ which means that the models did not present lack of fit. The errors could be considered randomly distributed around a zero mean value (i.e., are uncorrelated), which suggests a common constant variance. On the basis of this analysis, the regression model obtained was accepted to describe the effect of MVT and OPC contents on the SCC compressive strength.
The optimization plot of Figure 6 indicates that the maximum percentage of MVT that should be used in the SCCs is $30 \%$, which provides a 28 -day compressive strength of $25 \mathrm{MPa}$ with a degree of trust of 1 . The degree of trust of the optimization and the compressive strength tend to decrease considerably for dosages above $30 \%$ of MVT. Therefore, the proportion of MVT (as a replacement for type I Portland cement) should be limited in a range from $20 \%$ to $30 \%$. Considering the objective of this study to obtain SCC for lower strength applications incorporating high filler content and fluidizing effect of MVT on the fresh estate SCC properties, it was decided to use the maximum content of MVT (30\%) to evaluate the effect of this filler on rheological, mechanical and durability properties.

\subsection{Evaluation of the properties of self-compacting concrete with $30 \%$ volcanic material from Tolima volcano}

Table 5 presents the mixture proportions of SCC made with $30 \%$ MVT showing water/cementitious materials ratio, total content of cementitious materials, aggregate proportions and dosage of SP 

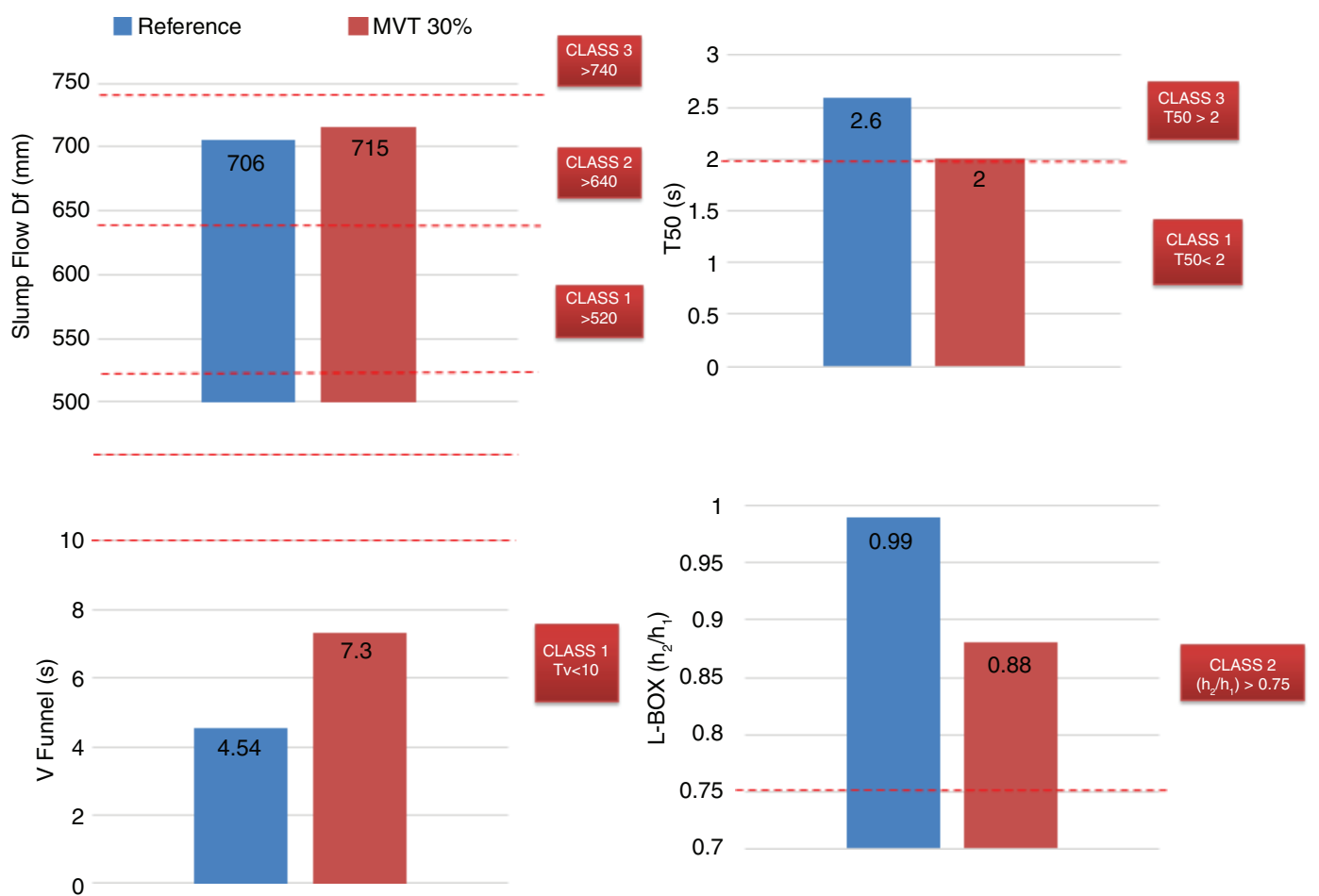

FIGURE 7. Comparison of the fresh state properties of SCC MVT $30 \%$ and SCC of reference.

were kept constant with respect to the reference SCC. Figure 7 presents a comparison of the fresh state properties between SCC MVT 30\% and reference SCC. The replacement of Portland cement by $30 \%$ MVT produced an increase in slump flow $\left(D_{f}\right)$ and $\mathrm{V}$ funnel time $\left(\mathrm{T}_{\mathrm{v}}\right)$ compared with the reference SCC. These results confirmed the fact that the addition of MVT increased the fluidity/flowability of the concrete up to a percentage of incorporation of $30 \%$. The use of MVT can reduce the cement content without reducing the total cementitious material content into the mixture and thus reduce the cost for SCC production.

According to the classification proposed by the European guidelines for SCC and considering the results obtained from fresh properties of SCCs (Figure 7). Reference SCC and SCC MVT 30\% belong to class $2 S F 2\left(660 \leq \mathrm{D}_{\mathrm{f}}<750 \mathrm{~mm}\right)$ in function of the slump flow diameter $\left(\mathrm{D}_{\mathrm{f}}\right)$. These kinds of concretes are appropriate for multiple applications, such as moderately reinforced walls and columns. On the other hand, the viscosity can be assessed by $\mathrm{T}_{50}$ time or by $\mathrm{V}$-funnel flow time $(\mathrm{TV})$. The time value obtained does not measure the viscosity of SCC, but is related to it by describing the rate of flow. Then, according to the classification, the SCC MVT $30 \%$ belong to class 1 VSI/VF1 $\left(\mathrm{T}_{50} \leq 2 \mathrm{~s}\right.$ and $\left.\mathrm{T}_{\mathrm{V}} \leq 8 \mathrm{~s}\right)$. This result confirms their good filling ability even with congested reinforcement. This SCC is capable of self-levelling and generally has the good surface finish, but is more likely to suffer from bleeding and segregation. While the SCC of reference could not be classified according to this parameter (flow time) because the time values were $\mathrm{T}_{50}>2 \mathrm{~s}$ and $\mathrm{T}_{\mathrm{V}}<8 \mathrm{~s}$, which did not fit within the European classification. With respect to passing ability (L-box), both mixtures presented values of $h_{2} / h_{1}>0.80$ using three bars as obstacle. Therefore, all the mixtures can be classified as class $P A_{2}$. This indicates that all mixtures of SCC have the ability to flow through confined spaces and narrow openings as well as densely reinforced structures, without segregation, losing of uniformity or blocking.

The mechanical properties of reference SCC and SCC MVT $30 \%$ at different curing times of up to 360 days are presented in Figure 8. The values shown are the mean value of 3 tested specimens. In general, the SCC MVT 30\% presented lower mechanical properties compared to SCC reference. Firstly, it was observed that SCC MVT 30\% reached 57\% of reference SCC compressive strength after 28 days, and $60 \%$ after 360 days with a compressive strength of $27 \mathrm{MPa}$. These results were similar to those reported by Hossain and Lachemi (8), who observed that the compressive strength of SCC decreased with the increase of volcanic ash content. Additionally, the tensile strength and flexural strength results showed similar trend as observed for compressive strength. After 28 days, reference SCC reached 5.7 MPa of flexural strength and 3.1 MPa of tensile strength 

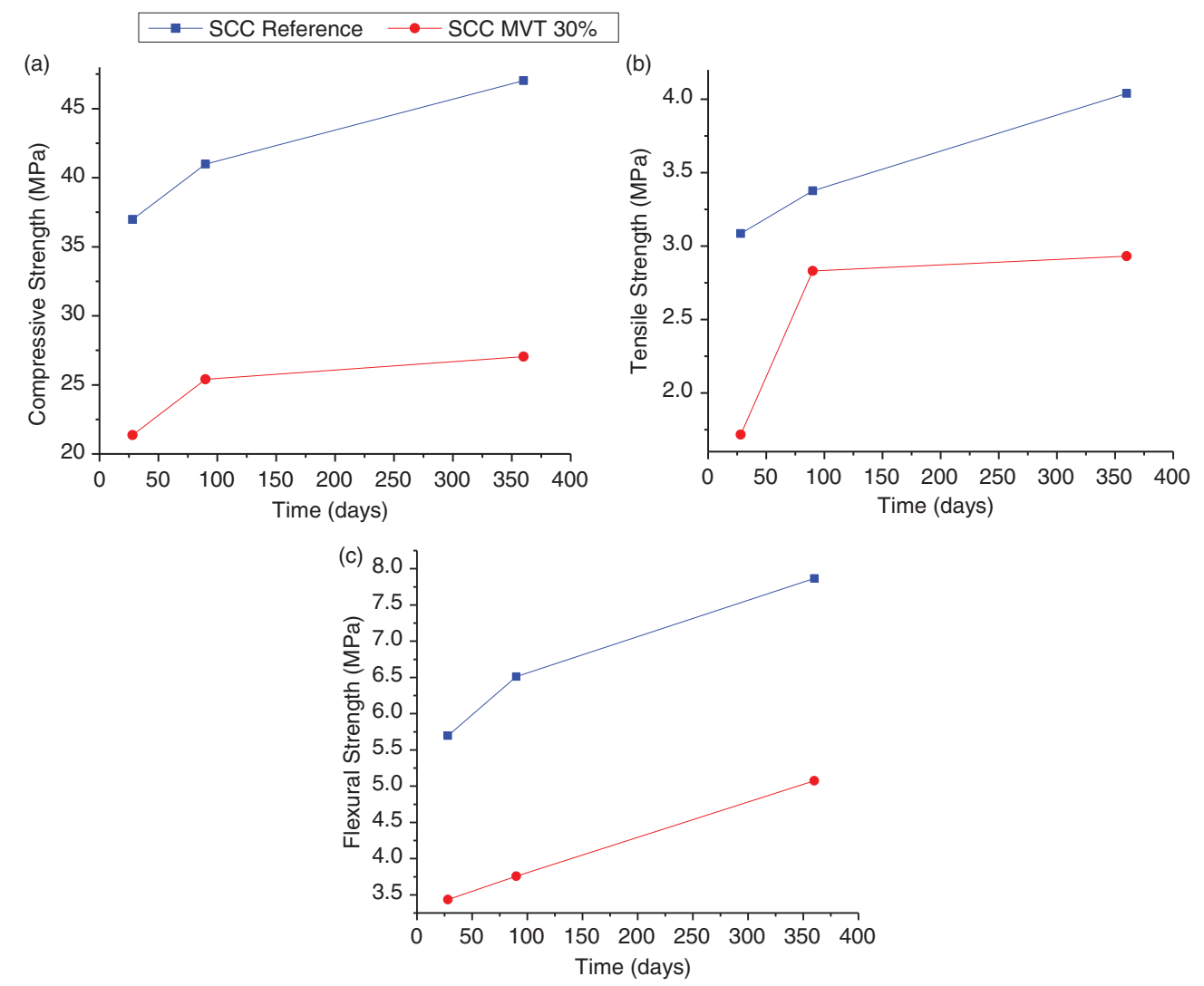

FIGURE 8. Mechanical properties of SCC MVT 30\% and Reference SCC: a) Compressive strength, b) Tensile strength and c) Flexural strength.

TABLE 6. Permeability properties of SCC MVT $30 \%$ and SCC of reference

\begin{tabular}{|c|c|c|c|c|c|c|}
\hline & \multicolumn{3}{|c|}{ SCC Reference } & \multicolumn{3}{|c|}{ SCC MVT 30\% } \\
\hline & 28 days & 90 days & 360 days & 28 days & 90 days & 360 days \\
\hline \multicolumn{7}{|c|}{ Density and voids in hardened concrete } \\
\hline Apparent Density $\left(\mathrm{kg} / \mathrm{m}^{3}\right)$ & 2630 & 2718 & 2642 & 2698 & 2771 & 2651 \\
\hline Volume of permeable voids ( $\%)$ & 14.62 & 15.43 & 17.94 & 21.44 & 22.99 & 17.01 \\
\hline \multicolumn{7}{|l|}{ Sorptivity Test } \\
\hline $\mathrm{K}\left(\mathrm{kg} / \mathrm{m}^{2} \mathrm{~s}^{1 / 2}\right)$ & 0.019 & 0.017 & 0.016 & 0.022 & 0.020 & 0.019 \\
\hline $\mathrm{m}\left(\mathrm{s} / \mathrm{m}^{2}\right) \times 10^{7}$ & 5.40 & 5.45 & 6.29 & 3.14 & 3.32 & 4.62 \\
\hline $\mathrm{S}\left(\mathrm{m} / \mathrm{s}^{1 / 2}\right) \times 10^{-4}$ & 1.36 & 1.35 & 1.26 & 1.78 & 1.74 & 1.47 \\
\hline Effective Porosity $\varepsilon_{0}(\%)$ & 14.04 & 12.86 & 11.53 & 12.53 & 12.8 & 13.17 \\
\hline
\end{tabular}

while SCC MVT 30\% presented 3.43 MPa of flexural strength and 1.7 MPa of tensile strength, showing an approximate reduction of $42 \%$. This behavior of SCC MVT 30\% (strength reduction) was expected, because of inert MVT addition which caused a dilution effect leading to a reduction of Portland cement content with consequent reduction in the volume of hydration products (23). Despite strength reduction, high proportions of volcanic material can be incorporated to produce low strength SCC attractive to non-structural applications such as precast structures of lower mechanical strength, where the high fluidity provide uniform formwork filling and the best surface finish. Such SCC can also be used in pressure-less molding systems.

Regarding permeability properties presented in Table 6, the values of apparent density of reference SCC and SCC MVT 30\% were approximately $2700 \mathrm{~kg} / \mathrm{m}^{3}$ for all curing ages. The density of SCCs were similar despite the difference between density of Portland cement $\left(3100 \mathrm{~kg} / \mathrm{m}^{3}\right)$ and MVT $\left(2090 \mathrm{~kg} / \mathrm{m}^{3}\right)$. With respect to the volume 
of permeable voids, the incorporation of MVT increased the percentage total voids of SCC in the hardened state. This explains the inferior mechanical behavior of the SCC MVT 30\% (in terms of lower strength) compared to its reference SCC counterpart. However, these results are not conclusive for durability properties of SCCs, because the percentage of total voids include all types of voids. As sorptivity test is related to the capillary structure of the concrete, it is effective in studying to the ingress of deteriorating substances into the concrete. For this reason, sorptivity test was carried out in order to know the SCC durability. In general, the sorptivity results were coherent with respect to the other evaluated hardened properties. SCC MVT 30\% presented higher rate of water absorption $(K)$ and consequent lower resistance to water penetration $(m)$, compared to reference SCC. This was attributed to the use of 30\% MVT (as cement replacement) as an inert filler altered the development of hydration process due to dilution effect as explained earlier. This behavior was also observed by Ramezananianpour, et al. (24), who found that an addition of limestone filler of up to $10 \%$ decreased the penetration depth as a result of the filling effect; with further addition of limestone content, the penetration depth increased as a result of heterogeneous nucleation and the dilution effect. Dogan and Ozkul (25) reported that the increasing of the paste volume caused an increase in capillary pore volume, which decreased the permeability resistance of SCC. Despite the findings of the previous research studies, it is worth noting that sorptivity index and effective porosity were found to very similar for SCC MVT 30\% and reference SCC, and these parameters decreased systematically with an increase in the curing age. These findings have a positive impact as they showed the possibility of incorporating MVT as an alternative filler in the production of SCC for lower strength applications with similar permeability properties compared to reference $\mathrm{SCC}$.

\section{CONCLUSIONS}

This article describes the development of a selfcompacting concrete (SCC) of lower strength by incorporating a volcanic material (MVT) filler as replacement for Portland cement type I. Considering the results of fresh and hardened state properties, the following conclusions were derived:

1. All SCCs with MVT presented suitable properties according to the European guidelines. It was observed that the MVT has a fluidizing effect on SCC up to a proportion of $28 \%$ by weight of cementitious material. SCC MVT 20\% and SCC MVT 28\% mixtures showed the best workability/stability characteristics without exhibiting segregation or bleeding.
2. The experimental results on mix designs showed that the compressive strength of SCC decreased with the incorporation of MVT. However, the analysis of the experimental design indicated that MVT can be used to produce SCC in proportions from $20 \%$ to $30 \%$ as a replacement for type I Portland cement at a composite desirability of 1 . Based on this, it was decided to use maximum content of MVT (30\%) to evaluate the effect of this filler on the rheological, mechanical and durability properties of SCCs. According to the fresh state properties, SCC MVT 30\% exhibited appropriate characteristics (good fluidity and passing ability) to be used in congested structures and structures with complex shapes.

3. Compressive strengths of $21 \mathrm{MPa}$ and $27 \mathrm{MPa}$ were obtained at 28 and 360 curing days, respectively with the incorporation of $30 \%$ MVT (as replacement of cement) in the SCC production with similar permeability properties compared to reference SCC $(0 \%$ MVT). These findings showed the viability of producing MVT based SCCs for applications such as some precast structures where high strength is not necessary. Additionally, the use of $30 \%$ MVT as a filler permits the production of environmentally friendly and low cost SCCs. The use of MVT as an alternative filler in the SCC production will have a positive impact in concrete industries, considering the abundant volcanic regions around the world.

\section{ACKNOWLEDGMENTS}

Authors would like to thank Universidad del Valle (Colombia) for its support for the development of this project. In particular, in this publication, partial results from the research project "Self-compacting concrete with volcanic materials", internal code 2785, supported by Universidad del Valle, Internal Call. We also acknowledge the donations of volcanic materials by the company CEMEX and Administrative Department for Science and Technology (COLCIENCIASCOLOMBIA) and their National Doctorates program for providing support. Also, the support given by the Centro de Excelencia en Nuevos Materiales (CENM) to the Grupo de Materiales Compuestos is also acknowledged.

\section{REFERENCES}

1. Kosmatka, S.H.; Kerkhoff, B.; Panarese, W.C.; Tanesi, J. (2004) Diseño y Control de Mezclas de Concreto. Director (Primera Ed). Skokie, Illinois: Portland Cement Association.

2. Rodríguez Viacava, I.; Aguado de Cea, A.; Rodríguez de Sensale, G. (2012) Self-compacting concrete of medium 
characteristic strength. Constr. Build. Mater. 30, 776-782. http://dx.doi.org/10.1016/j.conbuildmat.2011.12.070

3. Valdez, P.; Barragán, B.; Girbes, I.; Shuttleworth, N.; Cockburn, A. (2010) Uso de residuos de la industria del mármol como filler para la producción de hormigones autocompactantes. Mater. Construcc. 61 [301], 61-76. http://dx.doi.org/10.3989/mc.2010.55109

4. Felekoglu, B. (2007) Utilisation of high volumes of limestone quarry wastes in concrete industry (self-compacting concrete case). Resour. Conserv. Recy. 51 [4], 770-791. http://dx.doi.org/10.1016/j.resconrec.2006.12.004

5. Nagaratnam, B.H.; Rahman, M.E.; Mirasa, A.K.; Mannan, M.A. (2014) Workability of self-compacting concrete using blended waste materials. Adv. Mater. Res. 1043, 273-277. http://dx.doi.org/10.4028/www.scientific. net/AMR.1043.273

6. Massazza, F. (1993) Pozzolanic cements. Cem. Concr. Compos. 15 [4], 185-214. http://dx.doi.org/10.1016/0958-9465 (93) $90023-3$

7. Kirk, S.; Zuleta, R. (2000) A study of the volcanic ash originating from Mount Pinatubo, Philippines. Public Works. Philippines.

8. Hossain, K.; Lachemi, M. (2010) Fresh, mechanical, and durability characteristics of self-consolidating concrete incorporating volcanic ash. J. Mater. Civil Eng. 22 [7], 651-657. http://dx.doi.org/10.1061/(ASCE)MT.1943-5533.0000063

9. Güneyisi, E.; Gesoğlu, M.; Al-Rawi, S.; Mermerdaş, K. (2013) Effect of volcanic pumice powder on the fresh properties of self-compacting concretes with and without silica fume. Mater. Struc. 47 [11], 1857-1865. http://dx.doi. org/10.1617/s11527-013-0155-9

10. Celik, K.; Jackson, M.D.; Mancio, M.; Meral, C.; Emwas, A.-H.; Mehta, P.K.; Monteiro, P.J.M. (2014) High-volume natural volcanic pozzolan and limestone powder as partial replacements for portland cement in self-compacting and sustainable concrete. Cem. Concr. Compos. 45, 136-147. http://dx.doi.org/10.1016/j.cemconcomp.2013.09.003

11. American society for testing and materials, ASTM C494/ C494M-15a Standard specification for chemical admixtures for concrete. West Conshohocken, PA: ASTM, 2015.

12. Hossain, K. (2005) Volcanic ash and pumice as cement additives: pozzolanic, alkali-silica reaction and autoclave expansion characteristics. Cem. Concr. Res. 35 [6], 1141-1144. http://dx.doi.org/10.1016/j.cemconres.2004.09.025

13. Burgos, D.M.; Cardona, L.M.; Delvasto, S. (2014) Estudio de dos materiales volcánicos y efecto del tipo de molienda en su reactividad. Rev. Ing. Constr. 29 [2], 159-174. http:// dx.doi.org/10.4067/S0718-50732014000200003
14. Burgos, D.M.; Cardona Ramírez, L.M.; Gordillo Suárez, M.; Delvasto Arjona, S. (2015) Evaluation and pozzolanic effects of the puracé volcanic material. Rev. EIA. Esc. Ing. Antioq. [23], 83-93. http://www.scielo.org.co/scielo.php?script=sci arttext\&pid=S1794-12372015000100008\&lng $=$ en\&nrm $=$ is o\&tlng=es

15. Yahia, A.; Tanimura, M.; Shimoyama, Y. (2005) Rheological properties of highly flowable mortar containing limestone filler-effect of powder content and W/C ratio. Cem. Concr. Res. 35 [3], 532-539. http://dx.doi. org/10.1016/j.cemconres.2004.05.008

16. The European guidelines for self-compacting concrete. Farnham, Reino Unido, 2005.

17. American society for testing and materials, ASTM C39/ C39M-12 Standard test method for compressive strength of cylindrical concrete specimens. West Conshohocken, PA: ASTM, 2012

18. American society for testing and materials, ASTM C496/ C496 M-11 Standard test method for splitting tensile strength of cylindrical concrete specimens. West Conshohocken, PA: ASTM, 2011.

19. American society for testing and materials, ASTM C78/ C78 M-15a Standard test method for flexural strength of concrete (using simple beam with third-point loading). West Conshohocken, PA: ASTM, 2015.

20. American society for testing and materials, ASTM C642/ C642-13 Standard test method for density, absorption, and voids in hardened concrete. West Conshohocken, PA: ASTM, 2013.

21. Swiss federal laboratories for materials science and technologies (1989). EMPA - SIA 162/1 Test No. 5 - Water conductivity. Swiss federal laboratories for materials science and technologies: Zurich, Suiza.

22. Uysal, M.; Yilmaz, K. (2011) Effect of mineral admixtures on properties of self-compacting concrete. Cem. Concr. Compos. 33 [7], 771-776. http://dx.doi.org/10.1016/j. cemconcomp.2011.04.005

23. Bonavetti, V.L.; Rahhal, V.F. (2006) Interacción de Adiciones Minerales en Pastas de Cemento. Rev. Constr. 5 [2], 33-41. http://www.redalyc.org/articulo.oa?id=127619380004

24. Ramezanianpour, A.A.; Ghiasvand, E.; Nickseresht, I.; Mahdikhani, M.; Moodi, F. (2009) Influence of various amounts of limestone powder on performance of Portland limestone cement concretes. Cem. Concr. Compos. 31 [10], 715 720. http://dx.doi.org/10.1016/j.cemconcomp.2009.08.003

25. Dogan, U.A.; Ozkul, M.H. (2015) The effect of cement type on long-term transport properties of self-compacting concretes. Constr. Build. Mater. 96, 641-647. http://dx.doi. org/10.1016/j.conbuildmat.2015.08.097 